\title{
PELATIHAN "CO-FE (MICROSOFT OFFICE)" SEBAGAI UPAYA PEMBEKALAN SOFT SKILL DI BIDANG ILMU KOMPUTER BAGI PEMUDA PASCA LULUS SLTA DESA KESELET, SAKRA LOMBOK TIMUR
}

\author{
MUHAMMAD NURMAN \\ Dosen Prodi. Bahasa Arab, UIN Mataram \\ mesharamdhita@gmail.com
}

\begin{abstract}
Abstrak: Tujuan pengabdian ini untuk membekali ilmu berupa soft skill di bidang komputer terutama menggunakan microsoft office yang dapat menunjang kemampuan masyarakat sehingga mempunyai modal untuk bekerja dan bisa bersaing di dunia kerja.

Metode pemecahan masalah yang digunakan dalam kegiatan pengabdian pada masyarakat ini adalah dengan menggunakan metode: ceramah, diskusi dan praktek. Melalui gabungan metode-metode tersebut diharapkan mampu mempraktekan microsoft office. Agar program ini berjalan maksimal, maka diperlukan perencanaan atau persiapan, diantaranya: (a) Survei tempat pelaksanaan kegiatan, (b) Pembuatan proposal dan penyelesaian administrasi perijinan tempat atau lokasi pengabdian masyarakat, (c) Pembuatan modul pelatihan MS Word dan MS Excel, (d) Pembuatan atau pencarian video tutorial MS Word dan MS Excel (d) Perbanyakan modul sesuai dengan jumlah peserta. (e) Penentuan nara sumber.

Hasil pelaksanaan kegiatan: (1) Kegiatan Desa Binaan yang dilaksanakan dalam bentuk pelatihan Co-Fe (Microsoft Office) ini dapat terlaksana dengan baik dan lancar, meskipun tidak terlepas pula dari beberapa hambatan dan keterbatasan di lapangan. (2) Warga binaan memiliki keterampilan praktis sehingga menjadi bekal memasuki dunia kerja. (3) Warga binaan atau peserta pelatihan memiliki keterampilan life skill yang dapat dijadikan modal untuk mengikuti persaingan pada era dimana keterampilan dibidang komputer sangat dibutuhkan. (4) Warga binaan atau peserta pelatihan tidak asing lagi dengan istilah-istilah komputer yang mana selama ini mereka beranggapan bahwa komputer itu adalah suatu barang yang aneh bagi mereka dan tidak mungkin mereka dapat mengoperasikannya.
\end{abstract}

Kata Kunci: Pelatihan, Soft Skill, Komputer, Co-Fe (Microsoft Office).

\section{PENDAHULUAN}

Pengangguran umumnya disebabkan karena jumlah angkatan kerja tidak sebanding dengan jumlah lapangan pekerjaan yang mampu menyerapnya, skill yang dimiliki angkatan kerja juga belum mampu memenuhi permintaan pekerjaan yang ada. pengangguran seringkali menjadi masalah dalam perekonomian karena dengan adanya pengangguran, produktivitas dan pendapatan masyarakat akan berkurang sehingga dapat menyebabkan timbulnya kemiskinan dan masalahmasalahsosial lainnya. 
Berdasarkan data yang diperoleh bahwa angka pengangguran, ternyata di dominasi oleh lulusan SLTA, yang seharusnya mereka mendapatkan pekerjaan dengan mudah karena sudah memiliki keterampilan yang sudah mereka dapatkan di sekolah. Lulus SLTA adalah hal yang paling dinantikan oleh sebagaian remaja, karena sebagian dari mereka menyebut bahwa bangku SLTA adalah gerbang terakhir menuju kesuksesan. Mengapa demikian? Mungkin sebagian dari mereka menganggap bahwa setelah melepas baju putih abu-abu mereka akan terjun ke dunia kerja atau bangku kuliah yang menjadi awal titik menuju impian mereka. Tetapi tidak secara langsung dapat mereka nikmati karena ada banyak serangkaian persyaratan yang harus dimiliki. Instansi pemerintah maupun swasta mensyaratkan bahwa setiap karyawan harus memiliki skill, yang salah satunya adalah skill dibidang komputer yaitu minimal dapat menggunakan microsoft office.

Pengetahuan akan teknologi informasi sudah menjadi kebutuhan yang wajib dipenuhi di era globalisasi ini oleh seseorang. Salah satunya melalui ilmu komputer, ilmu komputer merupakan salah satu dari banyak keterampilan yang ada pada komputer dan merupakan salah satu dari banyak teknologi komputer yang banyak digunakan di dunia kerja nantinya. Hal ini dikarenakan program microsoft office dapat digunakan untuk mempermudah dan mengurangi tingkat kesalahan dalam bekerja, sehingga lebih efektif dan efisien.

Adapun ilmu komputer yang sering digunakan yaitu microsoft seperti $M S$ Word, MS Excel, dan MS power Point. Microsoft word merupakan program yang digunakan untuk pengolahan kata, mikrosoft exe/ yaitu program yang digunakan untuk mengolah data-data seperti penjumlahan, pengurangan dan sebagainya, sedangkan microsoft power point digunakan untuk membuat bahan persentasi di khalayak ramai. Dengan memahami program microsoft office anak-anak diharapkan mempunyai soft skill yang dapat dijaikan bekal yang berupa ilmu aplikatif yang langsung bisa diterapkan dalam kehidupan sehari-hari, mengingat maraknya penggunaan teknologi yang kurang baik oleh anak-anak program ini diharapkan mampu untuk meminimalisir penyalahgunaan terhadap penggunaan teknologi yang semakin maju. 
Memiliki kemampuan Microsoft Office, para lulusan SLTA juga dapat membuka jasa pengetikan atau dapat membuka lapangan pekerjaan sendiri dengan life skills yang mereka punya. Jadi apa yang mereka perbuat tidak hanya berguna bagi diri sendiri tetapi juga untuk orang lain, sehingga mampu mengurangi sedikit angka pengangguran di desa Keselet kecamatan Sakra Kabupaten Lombok Timur.

Berdasarkan uraian tersebut, dibutuhkan sebuah upaya pengabdian masyarakat guna membekali ilmu berupa soft skill di bidang komputer terutama menggunakan microsoft office yang dapat menunjang kemampuan masyarakat sehingga mempunyai modal untuk bekerja dan bisa bersaing di dunia kerja.

\section{PEMBAHASAN}

Sebelum pelaksanaan kegiatan pelatihan $\mathrm{Co}-\mathrm{Fe}$ (Microsoft Office), peserta pelatihan dikumpulkan untuk diberikan pengarahan oleh narasumber tentang tujuan dari kegiatan ini. Narasumber memberikan contoh dari hasil ketikan word dan excel dan membawakan beberapa perangkat keras komputer seperti printer, mouse, memori, keyboard serta memberikan contoh bagaimana cara penggunaan alat tersebut kepada warga belajar.

Tahap berikutnya, warga belajar mulai menggunakan komputer dan narasumber memberikan penjelasan tentang program microsoft word, cara memulai aplikasi, pengenalan judul windows, office button, custumize quick access tollbar, menu, toolbar, kursor, penggulung kertas serta memasukkan teks, memperbaiki teks, menggunakan mouse, menggunakan keyboard, menyimpan dokumen, menutup dokumen, membuka dokumen, keluar dari word, Serta pembimbing memberikan contoh cara menggunakannya.

Selanjutnya peserta pelatihan diberikan materi membuat naskah, mengatur setting halaman (margin dan ukuran kertas), tata cara penulisan naskah, pEraturan perataan teks, memformat karakter huruf pada teks, mengcopy kata atau kalimat, memindahkan kata atau kalimat, membatalkan perintah, Change case, Find, Reflace, and go to, setelah menyampaikan materi pembimbing menyarankan kepada para peserta untuk langsung mempraktekkan materi yang telah disampaikan dan narasumber melihat hasil ketikan peserta 
pelatihan apakah hasil ketikan sudah benar atau masih perlu bimbingan ulang. Narasumber juga memberikan materi yang baru yakni membuat tabel, fasilitas pengolahan tabel serta mempersilahkan kepada peserta pelatihan untuk menanyakan materi yang belum dikuasai.

Pada sesi berikutnya, narasumber memperkenalkan program mikrosoft exel dengan materi awal mengenalkan sheet pada program mikrosoft exel, langkah-langkah dalam memulai mikrosoft exel, mengimputkan data dalam sel, membuat kolom dan baris, sheet (lembar kerja) serta file. Selanjutnya narasumber membimbing para peserta pelatihan dalam mempraktekkan materi yang telah disampaikan. Peserta diminta untuk membuat sebuah file dalam bentuk excel kemudian setelah file selesai pembimbing menyampaikan materi fungsi penghitungan yakni materi operator matematika, fungsi sum, fungsi product, fungsi max, fungsi min, fungsi caout, fungsi raund, fungsi sqrt, fungsi power, fungsi sumsq, fungsi everage kemudian setelah materi disampaikan satu persatu peserta pelatihan langsung mempraktekkan materi yang disampaikan dengan bimbingan pembimbing.

Materi yang diberikan cukup memadai yaitu microsoft word dan mikrosoft exel. Materi yang diberikan ini disusun secara baik dan terperinci dalam sebuah modul. Namun yang menjadi masukan untuk perbaikan dimasa yang akan datang yaitu waktu pelatihan yang sangat singkat sehingga tidak semua materi secara maksimal dapat diberikan dengan baik. Pemateri sangat membantu peserta dalam memahami materi pelatihan, karena pemateri telah menempuh pendidikan formal sarjana dibidang komputer dan memiliki pengalaman mengajar yaitu mengajar mata pelajaran TIK di SMKN 2 Sakra. Pengelolaan kelas, dengan mengambil tempat di laboratorium komputer SMKN 2 Sakra sebagai tempat pelatihan telah memiliki komputer sebanyak 32 unit dengan spesifikasi komputer yang berkualitas, hal ini sangat membantu peserta dalam melakukan latihan microsoft word dan mikrosoft exel. Hal ini membuat peserta antusias mengikuti kegiatan pelatihan, sehingga dapat disimpulkan bahwa pelaksanaan kegiatan pelatihan ini berjalan dengan lancar dan hasil ujian praktek microsoft word dan mikrosoft exel menggambarkan bahwa peserta dianggap telah memiliki kemampuan atau menguasai dalam microsoft word dan mikrosoft exel. Adapun hasil ujian praktek tersebut adalah: 
Muhammad Nurman, Pelatihan "Co-Fe (Microsoft Office)"...

\begin{tabular}{|c|l|c|c|c|c|}
\hline \multirow{2}{*}{ No } & \multicolumn{1}{|c|}{ Nama } & \multicolumn{2}{|c|}{ Nilai } & \multirow{2}{*}{ Nilai } & Ket. \\
\cline { 3 - 4 } & & $\begin{array}{c}\text { Microsoft } \\
\text { Word }\end{array}$ & $\begin{array}{c}\text { Mikrosoft } \\
\text { exel }\end{array}$ & Akhir & \\
\hline 1 & Mahfuzoh & 85 & 75 & 80 & Lulus \\
\hline 2 & M. Sahril Ramdani & 80 & 75 & 78 & Lulus \\
\hline 3 & M. Yusriadi & 85 & 70 & 78 & Lulus \\
\hline 4 & Raudatul Zannah & 75 & 65 & 70 & Lulus \\
\hline 5 & L. Anden Singgih W & 80 & 75 & 78 & Lulus \\
\hline 6 & Nora Lija & 75 & 70 & 73 & Lulus \\
\hline 7 & Muslihatun & 75 & 65 & 70 & Lulus \\
\hline 8 & Ika Indra Dewi & 75 & 70 & 73 & Lulus \\
\hline 9 & Suriati & 85 & 70 & 78 & Lulus \\
\hline 10 & Sri Yatun & 80 & 80 & 80 & Lulus \\
\hline 11 & Winda Nisadi & 80 & 75 & 78 & Lulus \\
\hline 12 & Baiq Rahmayana P & 85 & 75 & 80 & Lulus \\
\hline 13 & Rika Apriani & 85 & 80 & 83 & Lulus \\
\hline 14 & Abdul Azis & 90 & 85 & 88 & Lulus \\
\hline 15 & Yanto Saputro & 90 & 80 & 85 & Lulus \\
\hline 16 & M. Zaini & 80 & 60 & 70 & Lulus \\
\hline 17 & Dendi Hardian & 75 & 65 & 70 & Lulus \\
\hline 18 & Rana Ilham Pratama & 90 & 85 & 88 & Lulus \\
\hline 19 & Nuril Erlina & 80 & 80 & 80 & Lulus \\
\hline 20 & Astuti Yuliana & 90 & 80 & 85 & Lulus \\
\hline 21 & Sahrul Huda & 70 & 70 & 70 & Lulus \\
\hline 22 & Nanang Nasrullah & 85 & 80 & 83 & Lulus \\
\hline 23 & Fitriani & 70 & 70 & 70 & Lulus \\
\hline 24 & Ari Supandi & 75 & 70 & 73 & Lulus \\
\hline 25 & Tatan Sopian & 80 & 75 & 78 & Lulus \\
\hline 26 & Nita Pebriani & 75 & 70 & 73 & Lulus \\
\hline 27 & Erlina & 70 & 70 & 70 & Lulus \\
\hline 28 & Emilia Widia Wasni & 70 & 70 & 70 & Lulus \\
\hline 29 & Siti Rahayu & 80 & 70 & 75 & Lulus \\
\hline 30 & Nur Aropah & 75 & 65 & 70 & Lulus \\
\hline 31 & Baiq Azhari Mawarni & 80 & 75 & 78 & Lulus \\
\hline
\end{tabular}

Selama dalam proses kegiatan pelaksanaan pelatihan yang dijalankan ditemukan beberapa temuan yang berhubungan dengan warga binaan atau peserta pelatihan, antara lain: (1) Latar pendidikan yang tidak sama, sehingga untuk memahami istilah-istilah komputer sangat heterogen. (2) Warga binaan belum seluruhnya memiliki perangkat komputer. (3) Warga binaan memiliki aktifitas atau rutinitas yang berbeda-beda sehingga agak sulit mengatur jadwal 
kegiatan pelatihan dan (4) Desa sebagai lokasi desa binaan tidak memiliki komputer yang memadai dari segi jumlah computer yang dibutuhkan.

Untuk mengatasi temuan yang ada, pendamping dan narasumber melakukan berbagai cara yang dapat dijadikan bahan pemecahan masalah yang timbul dari kegiatan pelatihan yang diselengarakan, diantaranya: (1) Lebih mengutamakan kegiatan praktik daripada teori. (2) Pengabdi berusaha menyediakan perangkat laptop berbanding : 1 yaitu dengan menyediakan tempat atau meminta izin kepada sekolah sebagai sarana tempat pelatihan komputer. (3) Pelatihan berkesinambungan, tidak hanya pada saat sekarang saja tetapi tetap membuka kesempatan kepada warga binaan untuk tetap berlatih, dan (4) Menyarankan dan mengarahkan pada warga binaan untuk mengikuti pelatihan lebih lanjut pada tempat-tempat kursus sehingga warga binaan memiliki sertifikat keahlian.

Berdasarkan hasil ujian praktek yang dilakukan, pelaksanaan kegiatan pelatihan ini dianggap sudah berhasil, karena semua peserta dinyatakan lulus. Hal ini diakibatkan: (1) Keingintahuan dari pada peserta yang cukup besar terhadap materi pelatihan yang diberikan dan (2) Antusiasme dan partisipasi aktif peserta.

\section{KESIMPULAN}

Dari kegiatan yang telah dilaksanakan, dapat simpulkan beberapa hal yaitu: a. Kegiatan Desa Binaan yang dilaksanakan dalam bentuk pelatihan Co-Fe (Microsoft Office) ini dapat terlaksana dengan baik dan lancar, meskipun tidak terlepas pula dari beberapa hambatan dan keterbatasan di lapangan.

b. Warga binaan memiliki keterampilan praktis sehingga menjadi bekal memasuki dunia kerja.

c. Warga binaan atau peserta pelatihan memiliki keterampilan life skill yang dapat dijadikan modal untuk mengikuti persaingan pada era dimana keterampilan dibidang komputer sangat dibutuhkan. 
Muhammad Nurman, Pelatihan "Co-Fe (Microsoft Office)"...

d. Warga binaan atau peserta pelatihan tidak asing lagi dengan istilah-istilah komputer yang mana selama ini mereka beranggapan bahwa komputer itu adalah suatu barang

Agar kemampuan warga binaan dapat selalu berkembang kemampuan dan dapat memasuki dunia kerja, warga belajar perlu mengikuti kegiatan lanjutan yaitu pelatihan atau kursus komputer guna untuk menambah pengetahuan yang sudah ada demi kemajuan pada masa yang akan datang.

\section{DAFTAR PUSTAKA}

Abdul Rajak, Penuntun praktis Microsoft Office XP. Surabaya Indah, 2002.

Ajen Dianawati, Belajar Komputer untuk Anak. Jakarta: Wahyu Media, 2006.

Ferry Zulkarnain, Mahir Menggambar dan Mewarnai dengan Microsoft Paint. Surabaya: Tiara Aksa, 2007.

Heinich, R, dkk., Instructional Technology and Media for Learning. Ohio: Merill Prentice Hall, 2003.

Hutchinson E. Sarah and Sawyer C. Stacey, Computers, Communications \& Information, McGraw Hill Companies Inc., 2000.

Indonesia Services Education HP Tim, Manajemen Sistem Belajar Di Dunia Maya, Majalah Info Komputer, 2001.

Jeffcoate Judith, Multimedia In Practice Technology and Applications, Prentice Hall International (UK) Limited, 1995.

Long Larry and Long Nancy, Computers $7^{\text {th }}$ Edition, Prentice-Hall Inc, 2000.

M.H Jogiyanto, Pengenalan Komputer, Andi Offset Yogyakarta, 1995.

Meier, D., The Accelerated Learning Handbook. New York: Mcgraw-Hill, 2000.

Nana Suarna, ST., Pedoman Panduan Praktikum Microsoft Office 2003. Bandung: Yrama Widya, 2006.

Newby, T.J. dkk., Instructional Tecnology for Teaching and Learning. New Jersey: Prentice Hall, 2000. 